\title{
Metáforas con futuro Los nuevos medios y la imaginación metafórica
}

\author{
Raúl Rodríguez Ferrándiz*
}

Recibido: 15 de octubre de 2008

Aprobado: 1 de noviembre de 2008

\section{Resumen}

Este artículo pretende repasar la historia de las metáforas que han servido para explicar los medios de comunicación, desde los medios difusivos, generalistas pero asimétricos, a los medios electrónicos, mucho más interactivos y cooperativos. Partimos del convencimiento de que las metáforas de los medios nos dicen mucho más de la percepción que de ellos se tiene, del sentimiento de fortaleza o de debilidad, de oportunidad o de amenaza que representan, de lo que pueda hacerlo un manual que describe con pretensión de objetividad científica. Más bien sucede que el desarrollo tecnológico, la sofisticación de los instrumentos y la multimedialidad de los nuevos medios no desplazan la pulsión metafórica, sino que la exacerban y la convierten en el único modo de entenderlos.

\section{Palabras clave}

Medios, metáfora, virtual, viral, interactivo, TIC

* Universidad de Alicante (España) r.rodriguez@ua.es 


\section{Metaphors with future. The new media and the metaphorical imagination}

\section{Abstract}

This article is intended to review history of metaphors which have been useful for explaining communication media, from the communicative, general, but asymmetrical media to the electronic media which are much more segmented, participative, and cooperative. We are convinced that media metaphors tell us much more of the perception people have about them; media metaphors tell us about the sense of opportunity or threat they represent; they tell us more than a manual which describes scientific objectivity. What it really happens is that the technological development, the sophistication of instruments, and the multimedial synergy of the new media do not displace the metaphorical drive; they exacerbate and make of it the only way to understand them.

\section{Key words}

Media, metaphor, virtual, interactive, TIC. 
Conocer no es sino trabajar con metáforas favoritas

\section{Friedrich Nietzsche}

\section{METAFORIZAR ES MEDIAR}

La metáfora, como nos enseñó Ortega, es la potencia más fértil que el hombre posee, «un trebejo de creación que Dios se dejó olvidado dentro de una de sus criaturas al tiempo de formarla». Todas las demás potencias humanas nos mantienen inscritos dentro de lo real, de lo que ya es, mientras la metáfora opera la suprema taumaturgia: «crea entre las cosas reales arrecifes imaginarios, florecimiento de islas ingrávidas» (Ortega, 1991, p. 36-37). Describiendo la metáfora, Ortega no hace sino metaforizar sin cesar y cabe preguntarse si la metáfora no será la más genuina expresión del hombre, si la expresión literal, propia, no es más que una entelequia, una metáfora de la que no somos conscientes, pero no menos tramada y urdida, un desvío del que ya no tenemos memoria ${ }^{1}$. No entraremos aquí en la genealogía de la metáfora, tema arduo, sino en sus efectos de sentido. La metáfora es artificio y como tal nunca es inocente. La metáfora muestra una faz interesada del objeto metaforizado. Es más, si la metáfora es lograda y alcanza repercusión social esa faz será decisiva, pues ese objeto ya no podrá desprenderse del foco que sobre él proyecta la metáfora, y que enaltece o caricaturiza alguno de sus rasgos despreciando los demás.

La metáfora es un poderoso instrumento ideológico. Quien crea y difunde una metáfora está construyendo el objeto metaforizado de una forma mucho más radical que quien lo describe con pretensión de objetividad científica. También ésta es construcción, como sabemos, pero deslavazada, de poco lustre y aliento, si la comparamos con la metáfora feliz. Describir es tomar partido, pero metaforizar es hacerlo a la vez elegante y persuasivamente ${ }^{2}$.

Quizá no sea inoportuno recordar que los medios de comunicación (de informaciones o de contenidos simbólicos, es decir, de mensajes) se emparientan con los medios de comunicación física (terrestre, marítima, aérea, que transportan pasajeros o mercancías) (Mattelart, 1995) y que los griegos modernos llaman hoy metaphorai a los transportes públicos: para ir a trabajar o volver a casa uno toma una «metáfora». Bien, mientras metáfora se ha concretado, corporeizado, encarnado en un objeto material (un autobús), los medios, que eran originalmente los de transporte y tenían una presencia física (los trenes, los barcos, el metro), se han desmaterializado, se han espiritualizado incluso: son ondas, emisiones, frecuencias, señales, que nos hablan a través de nuestros receptores de radio (como psicofonías hertzianas) o se manifiestan en nuestros receptores de televisión (como ectoplasmas catódicos).

\section{JERARQUÍA, ESPECTÁCULO, MONÓLOGO}

Los medios de comunicación, que comenzaron siendo metáforas de los medios de transporte, han llegado a arrebatarles la 
denominación: los medios o los media a secas, sin apellidos, son los de comunicación. Es decir, los medios de comunicación de masas ya no son los trenes, los barcos o el metro, como quizá fuera más propio en el sentido original, hoy traslaticio, metafórico precisamente, sino la prensa, la radio y la televisión. En cualquier caso, la querencia por la metáfora es imparable, y los medios (de comunicación de masas), que nacieron de los medios de transporte por metáfora han inspirado a su vez, en su historia ya centenaria, infinidad de metáforas, que son como declinaciones tardías, variaciones de aquella original. Francesco Casetti (1992, p. 45-51) las ha resumido en tres grandes grupos ${ }^{3}$. Por un lado, los medios pueden ser entendidos como medios de difusión, es decir, instrumentos que permiten la circulación de informaciones, ideas, proyectos, visiones del mundo. En esta perspectiva, los medios pueden imaginarse como megáfonos que amplifican un mensaje extendiendo su alcance sin alterarlo, un mensaje que por otra parte existiría igualmente sin amplificación, aunque sería más débil. Es evidente que aquí se privilegia el canal de transmisión sobre otras consideraciones, y el debate se establece en torno a los «tiempos de ocupación» del medio, en la búsqueda de repartos equitativos entre los actores sociales. Ahora bien, esta interpretación también consiente imágenes disfóricas o disfuncionales: el medio bien como cetro, que otorga autoridad y credibilidad a quien lo porta con independencia del origen de su legitimidad, bien como pífano o reclamo, que llama la atención sobre sí y hace apetecible aquello que exhibe: es decir, el medio ya no es un amplificador neutro, sino que quien lo controla goza de una ventaja cualitativa, un rol de guía políti- co, cultural, económico, un escaparate privilegiado para la moda y el consumo.

En segundo lugar los medios pueden ser entendidos como medios de representación del mundo, bien el mundo efectivo, bien un mundo imaginado. Aquí está en juego la habilidad de los medios para captar, fijar y devolvernos porciones de mundo acaso inaccesibles a nuestros sentidos, o de proveer dispositivos para describirnos esos mundos imaginados: el mundo interior del artista, el imaginario colectivo de lo temido o de lo deseado. La imagen más consistente de esta actitud ante los medios es la del espejo, y la idea que la sustenta es que los medios reflejan algo que existe en algún lugar. Como en el caso anterior, el lado oscuro está al cabo de la calle: los medios pueden entenderse también como puestas en escena de una realidad construida, tamizada por filtros como la oportunidad o el interés, y estructurada según reglas de género impuestas, ajenas a la realidad como dato en bruto. Si aducimos que éste sería difícilmente comprensible sin una elaboración previa, los medios pueden imaginarse como mapas, es decir, transcripciones convencionales del territorio para proveer una más fácil orientación, pero si juzgamos que ese mapa suplanta a menudo al territorio y se apropia de todas sus propiedades y efectos, entonces los medios producen simulacros.

Por último los medios pueden ser abordados como medios de relación, es decir, entenderse como espacios donde los actores sociales interactúan, negocian, discuten, rivalizan. Aquí se privilegia no su función instrumental ni los contenidos que vehiculan, sino el contacto que facilitan entre los interlocutores que se sirven de ellos. Por un 
lado es posible imaginarlos como plaza pública, donde caben quien reivindica atención para su problema, quien vende y quien compra, quien expone sus opiniones y sus proyectos, quien cuenta una historia o relata su experiencia, quien discute y quien simplemente se divierte o mira pasar la vida. Pero también son juzgados como una farsa de relación interpersonal, pues el contacto es imaginario: una multitud de discursos no hacen una discusión, y un receptor que los escucha todos no es un destinatario privilegiado, sino mudo y resignado al anonimato. Así pues, los medios también condenan al aislamiento y vacían incluso los tradicionales foros de intercambio verdadero, es decir, construyen un desierto y extinguen las demás voces para imponernos su monólogo.

Megáfono, cetro, pífano, espejo, escena, mapa, simulacro, plaza y desierto son imágenes sólidas de los medios, adecuadas a un cierto aspecto considerado y a un juicio valorativo. Se nos ocurre añadir a las de Casetti otra dicotomía de metáforas, que en este caso no se encarnan en objetos reales sino imaginarios, procedentes de la creación literaria y del utopismo filosófico. En atención al alcance totalizador, a la visibilidad absoluta y minuciosa que procuran, los medios, sobre todo la televisión, pueden ser también el aleph borgiano -la totalidad maravillada del vero pueden ser el panóptico benthamiano, pasado por el pesimismo de Foucault: la totalidad monstruosa del ser visto ${ }^{4}$.

Esta relación de metáforas se refiere a los medios de comunicación social clásicos, digamos, desde la prensa a la televisión. Las llamadas nuevas tecnologías de la comuni- cación, las propias de la revolución digital, han deparado nuevas metáforas, que en ciertos casos se oponen y en otros abundan en las ya consolidadas. Si convenimos en que la metáfora es un filtro a través del cual se puede aprehender la realidad objeto de nuestras apetencias cognoscitivas y que ese filtro se vuelve imprescindible precisamente allí donde la teorización directa es difícil, sea por la novedad del objeto o por la inmadurez de la disciplina, entonces admitiremos su papel determinante en la percepción «populars de las nuevas tecnologías.

\section{LIBERTAD, COOPERATIVISMO, EQUIPOLENCIA}

Asumir que el ordenador es un cerebro electrónico, una inteligencia artificial, y hablar con naturalidad no sólo ya de su «memoria» (un dispositivo interno), sino de las interfaces que nos muestra y nos ofrece al intercambio comunicativo, es decir, de sus «sentidos» externos (vista, oído, tacto: el ordenador literalmente «da la cara» y nos interpela en un «careo»). Suponer que la pantalla es un escritorio vertical donde colocamos las carpetas repletas de archivos, con sus etiquetas, un reloj con hora, día y mes, una agenda, un álbum de fotos, una discoteca, un diccionario o enciclopedia, bases de datos especializadas, incluso un mapa. Recorrer las autopistas de la información con mayor a menor celeridad debido a la saturación del tráfico o a los peajes y cargar o descargar información como quien maneja una mercancía, o bien detenerse para comprar en los grandes centros comerciales de la red 
electrónica, o tal vez echar un vistazo sin pretensión de comprar nada (browser, to browse: hojear libros o revistas en una librería o mirar objetos en una tienda), recorrer con la mirada los estantes, ampliar el producto y comparar las características entre productos, probarlo gratuitamente hasta el momento fatídico en que se nos requiere el número de nuestra tarjeta de crédito. Entrar en portales que nos interrogan con un sinnúmero de accesos en un recorrido laberíntico, encontrar el camino y visitar sitios nuevos, extraviarse, llegar a un callejón sin salida, topar con un tramo en obras. Navegar como timonel (kybernetés es eso en griego) en el incógnito mar de la información con el horizonte como límite siempre inalcanzable, siempre diferido, moverse por la red rizomática de contactos horizontales, o bien quedar atrapado en ella a merced de un oportunista, como un incauto pez en la red del pescador de contraseñas (phishing). Cortar y pegar sin importarnos que eso que cortamos y pegamos no es materia, y ni siquiera es espacio, sino a menudo espacio-tiempo (un fragmento de película) o bien sólo tiempo (una secuencia de notas musicales). Desplegar un menú en cascada, más una carta completísima que un menú, en realidad, ordenar los documentos en archivadores que contienen carpetas y subcarpetas, receptáculos ya no sólo de documentos de texto o de fotos (que son superficies aptas para yuxtaponerse en una carpeta), sino de volúmenes (libros, cintas de vídeo, álbumes musicales, objetos tridimensionales). Infectar o ser infectados por un virus agresivo y desconocido que se transmite pandémicamente y probar varios antídotos hasta neutralizarlo. Sumergirnos en la realidad virtual y sentirnos envueltos por ella como en un líquido amniótico, desplazarnos con la torpeza de movimientos de un buzo o de un durmiente en sus sueños (o pesadillas). Todas son metáforas de las nuevas tecnologías digitales, y cada una de ellas funciona como núcleo en torno al cual se arraciman un conjunto de términos que la prolongan y la consolidan, que crean todo un campo semántico metafórico coherente ${ }^{5}$.

Lo más estimulante de las metáforas asociadas a las nuevas tecnologías de la comunicación es cómo a través de ellas pretenden distanciarse de las «antiguas», oponiéndose a las metáforas -en general disfóricas- que éstas sugirieron en su día (Giraldo Ramírez, 2004). Y así las nuevas se asocian a las imágenes de horizontalidad (frente a la verticalidad jerarquizada de los medios tradicionales: el cetro que decía Casetti), de reticularidad o rizoma (con conexiones equipolentes y ajenas a cualquier centro o núcleo rector), de fluidez, maleabilidad, modularidad, polivalencia, usabilidad frente a la rigidez, solidez, pesadez hardware de los medios clásicos, de libertad y creatividad frente al modelo unidireccional y difusivo, estandarizado y serializado. Ese nuevo imaginario mediático sin duda tiene que ver con el más general imaginario postindustrial: ya no es la cadena de montaje lubricada pero ensordecedora, que ensambla piezas sólidas y vomita miles de copias idénticas que serán distribuidas desde el centro productor a la más remota periferia por los medios de transporte, sino más bien intervenciones ubicuas y a menudo anónimas, que inoculan en la red fórmulas magistrales que se contagiarán pandémicamente, que circularán como flujos sin un centro rector y sufriendo por el camino incontables mutaciones. 
Si el libro es un volumen voluminoso, un «paralelepípedo brusco y mohoso» como decía Sartre (pero tan irresistible para él), un edificio edificante, un objeto dotado de tapas que lo limitan y lo preservan, que preservan sobre todo la atribución del contenido a un autor, amurallado, protegido y por ello mismo también protector, el texto en la pantalla del ordenador, y más el hipertexto en que se metamorfosea y funde, es en cambio volátil y maleable: textos sin bordes rígidos, sin cáscara, que circulan por una biblioteca sin muros ni estanterías, que se yuxtaponen, que desafían la auctoritas de su autor y la contrastan, la recrean, la remedan, la remiendan, la enfrentan a otras autoridades menos autorizadas por la tradición y el canon. Por el texto pasamos como el arado sobre la tierra, reabriendo esos surcos que son las líneas de lo impreso, por el hipertexto en cambio navegamos en una superficie sin límites ni fronteras, sin caminos trillados, al albur de los vientos y de las mareas de nuestra inquietud. Pero no sólo seguimos pistas ajenas, sino que las trazamos para otros. El lector de libros electrónicos o en general de textos literarios en soporte digital muestra una tendencia irrefrenable hacia la interpolación, la glosa y la crítica de esos textos, que adjunta al original, y los amplía y los hace proliferar, y ello no sólo mediante citas de otros textos - precursores, deudores, apologistas, contradictores- que invita a cotejar con el texto en cuestión objeto de su desvelo, sino mediante aportaciones propias que teje y que ofrece a su vez al tejido de otros, pues la herramienta informática consiste precisamente en facilitar esa labor hipertextual.
Y lo que acontece con la cultura impresa en el entorno de las nuevas tecnologías tiene su correlato en otros dominios culturales: el aficionado a la música no sólo reproduce cuantas veces quiera las piezas del producto que adquirió, sino también selecciona sus tracks preferidos, los renombra y compila a su gusto, produciendo un conjunto de piezas inédito, incluso las puede editar, samplear, es decir, posproduce el producto para hacer una escucha a medida; el aficionado a la pintura captura en la red o escanea una reproducción impresa y la retoca a su gusto, apropiándosela, y de igual manera puede proceder el aficionado a la fotografía que recurre a fotos ajenas o a un «banco de imágenes» y aplica sobre ese material tecnologías infográficas; el cinéfilo y videoaficionado no sólo reproducen películas por un lado y graban vídeos domésticos o DVD por otro, sino que editan, sonorizan, introducen carteles o subtítulos, efectos visuales, confeccionan sus propios trailers, compilan antologías de escenas preferidas, por directores, por actores, por géneros, por asuntos, y los bloggers, ápices de toda esta babel electrónica, compaginan todas las destrezas multimediales antedichas y multiplican su circulación. Hasta el telespectador, ejemplo en tiempos de la desidia casi catatónica ante el estímulo catódico, diseña su propio pasto televisivo en tanto zapper, de manera que no hay dos veladas televisivas rigurosamente idénticas para dos conciudadanos ni convecinos, ni siquiera para quienes comparten vivienda incluso.

Parece evidente, por tanto:

1) que toda recepción y todo consumo se vuelven productivos, creativos, 2) que esos productos sin embargo no son de 
una vez por todas, es decir, no se congelan o acrisolan en una forma estable que permita su comercialización (y el fetichismo de la mercancía consecuente), sino que circulan en incontables versiones, y 3) que, en fin, el acrecentamiento de la propiedad cultural del otro no mengua ni amenaza la propia, sino que la refuerza en intercambios cooperativos (las licencias creative commons $\mathrm{y}$ los copy-lefts, los protocolos p2p de intercambio de archivos mp3 y la circulación de software libre).

\section{VIRTUD Y VICIO}

Virtualidad e interactividad, tótems en torno a los cuales gira todo ese carrusel metafórico, son los emblemas rotundos que definen el aire del tiempo, como en otros tiempos lo fueron los términos evolución, energía, inconsciente, estructura o código. Se habla profusamente de experiencias, comunidades, presencias virtuales y de programas, aplicaciones, posibilidades interactivas. La relación entre ellas es estrecha: por un lado la interactividad es una forma de llamar a una interacción simulada -virtual diríamos en esta jerga- entre el ordenador y su usuario, y por otro la virtualidad es precisamente lo que promueve la interactividad, porque si las consecuencias de nuestras tropelías con los ordenadores fueran reales no interactuaríamos con ellos. Las nociones de virtualidad y de interactividad son no menos metafóricas, y a menudo hiperbólicas, que las vistas hasta aquí. Diremos más: virtualidad e interactividad son incluso rasgos pertinentes de toda metáfora, su esencia más genuina. La metáfora parece participar de lo virtual (simplificando mucho en una metáfora una cosa es -virtualmente- otra) y de la interactividad (la metáfora no es meramente sustitución del término propio o literal, sino que interactúa con éste quedando ambos afectados en sus perfiles semánticos y pragmáticos).

Analicemos los términos «virtual»e «interactivo». Decimos que una cosa es virtual cuando es en potencia y no en acto, cuando no actualiza, aunque eventualmente podría, un cúmulo de potencialidades. Etimológicamente virtual se emparenta con virtud. Como dice el DRAE, virtual es «que tiene virtud para producir un efecto, aunque no lo produce de presente», y señala que se usa habitualmente como antónimo de «real» o «efectivo». De esa «virtud» latente original el desplazamiento de significado hacia el lado de un «vicio» latente está al cabo de la calle: una segunda acepción habla de «implícito, tácito» y una tercera define virtual como «que tiene existencia aparente y no real». Es decir, lo virtual se puede deslizar con facilidad desde lo que no siendo podría ser (y somos conscientes tanto de la ausencia actual como de la potencia latente) a lo que no siendo se presenta como lo que es (y por lo tanto engaña a algunos incautos, pero hace disfrutar y experimentar a quienes están en el secreto).

Para algunos pues virtual indica un cúmulo de posibilidades aún por desarrollar y una reserva de experiencias nuevas que probar. Con el tiempo la virtualidad de las experiencias se desgastará al incorporarlas a nuestras expectativas, pero no hay cuidado, pues al mismo tiempo se abrirán horizontes y perspectivas aún más lejanos: es el mito del progreso en clave de virtualidades atis- 
badas y finalmente conquistadas, con nuevas islas a la vista. El tiempo, pues, juega a favor de estos adoradores de la virtualidad, de manera que si ya son posibles la comunidad virtual, la economía virtual, la guerra virtual, pronto alcanzaremos la democracia virtual, la cirugía virtual, el turismo virtual, el sueño virtual, el sexo virtual. Para éstos la virtualidad tiene muchas ventajas. La asepsia, la reversibilidad (nada es definitivo e irremediable si es virtual), la imaginación sin lí mites. Esa confianza a menudo se está demostrando suicida. Se diría que para muchos lo virtual es una especie de luz sin sombra, pero eso es un imposible: la alianza que une, como no podía ser de otra manera salvo por ingenua superstición de novedad, a lo virtual con lo real acecha siempre. Lo virtual y lo real no son términos opuestos sino complementarios. Todo lo real tiene virtualidades, todo lo virtual aspira a manifestarse en la realidad (Yus, 2007).

Para otros la virtualidad es una máquina de simulacros que avanza invadiendo la realidad real y suplantándola. Lo virtual crece a expensas de lo real, cada vez más empequeñecido, periférico, residual. Lo virtual ya no es una parcela bien acotada que cuenta con nuestra tolerante complicidad, sino que pro gresa metastásicamente usurpando los ámbitos de nuestra vida cotidiana y nuestra privacidad: es la invasión de los simulacros, es decir, la metáfora que Casetti señalaba para los medios tradicionales, trasladada y reforzada exponencialmente en los nuevos. Este tremendismo tampoco trae nada bueno. En unos casos se denuncia la aceleración de la experiencia y el accidente cósmico al que nos arriesgamos por jugar con una red también planetaria (Virilio, 1997, 1999), sin proponer ninguna alternativa más que una vaga nostalgia por tiempos más lentos y espacios más localizados. En otros casos la contumacia contra lo virtual, a toda costa, hace perder de vista las consecuencias reales, que son las verdaderamente terribles ${ }^{6}$.

Frente a una virtualidad que se concibe, bien como solución a las imperfecciones de todo lo físicamente existente, es decir, una virtualidad que mejora lo real (la idea de los utópicos y los eufóricos de la TIC), bien como una limitación decepcionante y embaucadora (la de los distópicos y catastrofistas), una tercera de compromiso, menos maximalista, se insinúa: una virtualidad tejida en la realidad, en constante interacción con ella (Yus, 2007).

En cuanto a la interactividad, se pone el acento en que la televisión nos mantenía pasivos, inertes y narcotizados ante su pantalla, mientras que la pantalla del ordenador conectado a la red nos ofrece una participación, de alcance y osadía siempre creciente y siempre gratificante. Se contrapone el couch potato televisivo, colmo de la indolencia y de la vida vegetativa, al dinámico internauta, que pulsa su teclado con fruición y pilota su propia nave de intereses y deseos por las costas y los puertos de la geografía digital. La confusión o la impropiedad en este ámbito también son manifiestas. Toda la mitología de la interactividad está atravesada por el prejuicio de que la participación ha de ser observable, es decir, de que debe manifestarse como una conducta (pulsar un botón, mover el cuerpo), como si las elipsis en la narración literaria o cinematográfica, o los atajos de la representación en las artes visuales espaciales, no promovieran y hasta exigieran una interacción (psicológica en este caso) por parte del lector o espectador 
(Manovich, 2005, 103-109). Pero incluso aquí se muestra vacilante: desde ese punto de vista, nada más pasivo y ensimismado que la lectura de un libro. Inmovilizado, abstraído del mundo alrededor, el lector no suele demostrar exteriormente ninguna alteración achacable a lo que lee, pero a nadie se le ocurre acusar al lector impenitente de «pasivo». La lectura es participante, co-creadora, lo mismo que la sesión televisiva provoca inapelablemente -se afirma- una lasitud opiácea. Y en cuanto al internauta, a menudo se olvida que la comunicación a través de chats o de correo electrónico, de skype o a través de web-cam no es en absoluto interactividad (o no sólo interactividad), sino interacción comunicativa (más rica y plena) entre seres humanos mediada por la técnica.

Ahora bien, como ya señaló Rolf Meyersohn en los 50 a propósito del debate sobre la «pasividad» televisiva, una cosa es afirmar que el uso del medio es en sí un acto pasivo y otra decir que el medio tecnológico conduce a su usuario a la pasividad. La pasividad, en todo caso, es una característica humana, no de la televisión ni de ningún artilugio, y conviene por tanto ser muy cautos con todos los determinismos tecnológicos, que según sea la tecnología impondrían actividad o pasividad.

En otras palabras, la posibilidad de respuesta articulada y selectiva de contenidos o de itinerarios por parte del internauta es sin duda mayor que la del televidente no sólo de las televisiones generalistas, sino también de las temáticas y segmentadas, pero ello no permite generalizaciones a propósito de la «personalidad» de los usuarios respectivos, ni menos todavía aleluyas so- bre un espíritu del tiempo más democrático e igualitario, más entusiasta y seguro de sí, más creativo y vanguardista ${ }^{7}$.

\section{LOS SENDEROS QUE SE BIFURCAN: SALTAR CON RED}

Se dice que ya no tenemos creación de un lado y disfrute de otro, sin posibilidad de reversibilidad, sino co-producción, confección por ambas partes. Pero no se trata sólo de matar al autor en el sentido fuerte y que sea llegada la hora del lector, del espectador o del oyente, que asumen en parte su papel. Se diría que ni la idea de creación ni la de producción designan ya, en esta etapa de virtualidades e interactividades, el acto positivo de imposición de un nuevo orden, sino más bien el gesto negativo de la elección, con lo que ella supone de limitación de posibilidades, de privilegio de una opción sobre las otras. De ahí que o bien esa decisión de cierre es compartida, o bien es reversible en cierto modo, es transitable en todo momento hacia un nodo decisional anterior. Es como si nadie asumiera la responsabilidad de tomar resueltamente, en el jardín desconocido, uno de los senderos que se bifurcan, por recordar el cuento borgiano, $\mathrm{y}$ todos quisieran poder recorrer narrativamente todas las alternativas.

Que esa perspectiva pueda ser tan estimulante (por una especie de narcisismo autoral que recae en el destinatario, empoderado creativamente), como, en ciertos aspectos, también frustrante (pues sin destino irreversible se hacen imposibles tan- 
to la identificación como la catarsis, y la copresencia constante de las alternativas resta credibilidad al relato y limita más -paradójicamente- lo que podemos esperar de él) es algo que no podemos abordar ahora. Digamos sólo que la libertad de elección descansa sobre la multiplicidad de posibilidades, pero sería una libertad vacía aquella que rechazase el derecho a poner una posibilidad por encima de las otras -a reducir la multiplicidad de oportunidades, a cerrar y rechazar las posibilidades indeseadas- en otras palabras, que recortase o cancelase por completo la elección: la esencia de la elección es el esfuerzo para abolir la elección, y la irreversibilidad de la elección que se escoge es lo que la hace valiosa y entrañada.

Es posible, además, que ese consumidor participante, que por un lado se estimula, indaga, tantea, crea y comparte, por otro puede en cierto modo llegar a enorgullecerse de su propia trivialidad, sin conciencia clara de lo que debe y deja en herencia, impulsado por un presentismo que confunde la Red, en cada instante de su acceso, con los límites de lo cognoscible, lo inteligible y también lo usable, en tanto bricoleur.

En cualquier caso, sean beneficios o perjuicios los que avizoramos, la potencia metafórica de los nuevos medios no decae, sino que se exacerba: la creciente abstracción y complicación de las operaciones, las programaciones, los protocolos del hardware tiene su correlato en un software usable, confiable, reconocible, cercano, vía metafórica. Pero no sólo eso, sino también en cierto modo lo contrario: el funcionamiento del cerebro humano, que es nuestra caja negra, parece alcanzar una iluminación a partir de las operaciones informáticas que pretenden reproducirlo. El deseo de exteriorizar y objetivar las operaciones de la mente se muestra en el imaginario metafórico de la informática más poderoso que en el imaginario metafórico de los medios tradicionales: en el cine, la televisión o la publicidad exterior se nos instaba a que nos identificáramos con la imagen corporal de otras personas, así como, desde luego, asumiéramos o rechazáramos patrones de conducta. Esa identificación y/o proyección eran de adhesión o rechazo, miméticas o catárticas, pero más simples quizá de lo que propone el nuevo imaginario: el principio del hipervínculo, punto de partida de los medios interactivos, parece objetivar el principio de asociación mental: los procesos de reflexión, resolución de problemas, recuerdo son equiparados a las tareas de seguir un enlace, cambiar de página o escoger una nueva imagen o una nueva escena relacionada con la anterior. Se trata de una reedición actualizada de la pretensión de un isomorfismo de las representaciones y operaciones mentales con los efectos visuales externos, en la que la metáfora (como la historicidad y caducidad de esos traslados debería enseñarnos) se tiene por una descripción objetiva.

\section{CONCLUSIONES}

Hemos perseguido las huellas de la metáfora en la mediología, desde los medios masivos tradicionales -en los que se alternan o se complementan las grandes matrices metafóricas de la onda expansiva (el medio como difusor), del espejo (el medio como representación o puesta en escena) o de la plaza pública (el medio como espacio de rela- 
ción) hasta la revolución de la informática y la telemática (las TIC como redes multipolentes, conviviales, interactivas e intertextuales). Y hemos visto que el repaso a las metáforas de los medios sin duda enseña algo sobre los medios, pero sobre todo enseña algo sobre las metáforas. Por un lado, la persistencia del anhelo de entender y explicar lo nuevo por lo conocido, pero lo radicalmente interesado de ese didactismo metafórico, tan proclive a deslizarse al imaginario de lo deseable o de lo execrable. Por otro, la potencia creativa de la metáfora, capaz no sólo de iluminar el objeto dado, sino de construirlo de forma inédita y de adjetivarlo, de promover en torno a él una verdadera constelación de objetos vinculados y de prácticas que dan forma a un paisaje y a un utillaje. Y finalmente el valor heurístico de la metáfora en forma retroactiva, es decir, cómo las metáforas que usamos para los instrumentos del comunicar, a menudo antropomorfas, nos iluminan de vuelta a nosotros, sus creadores, como sofisticados artilugios de elaborar y gestionar la comunicación.

\section{NOTAS}

1 Sobre la metáfora, tema arduo y en absoluto resuelto por los investigadores, nada mejor que recurrir a los textos, ya canónicos, de Richards (1936), Black (1966), Ricoeur (1980), el Groupe $\mu$ (1987) y Lakoff y Johnson (1980), textos que plantean una discusión sobre la naturaleza, función y alcance de la metáfora en la que no podemos entrar aquí. Para la aproximación a una consideración cognitiva de la metáfora en la línea de los últimos autores citados, cfr. las aportaciones de Indurkhya (1992), De Bustos (2000) y los propios Lakoff y Johnson (2007).

2 Cuando el ex-vicepresidente de los EE. UU. Al Gore presentó su informe sobre las «autopistas de la información» esa metáfora no sólo estaba dando visibilidad y concreción a un complejo mecanismo telemático cuyo funcionamiento escapaba entonces y escapa hoy al ciudadano medio que ya es su usuario, sino que establecía la conveniencia de impulsar con decisión esas vías rápidas de información. De la misma manera que en los años cincuenta y sesenta la obsoleta red viaria norteamericana fue sustituida por una red de autopistas interestatales y ello propició un extraordinario desarrollo económico, así las comunicaciones telemáticas de los noventa debían discurrir por vías holgadas que permitieran una alta densidad de tráfico, y era necesario intervenir, regular e invertir en dichas infraestructuras viarias. Es más: las autopistas de la información no sólo nos habrían de permitir recorrer con mayor agilidad un ciberespacio, sino que serían también autopistas en el tiempo, abiertas a un futuro radiante de las telecomunicaciones en pro de la transparencia informativa, de la educación, de la medicina, del comercio, del ocio, de la investigación y la ciencia. Toda una política a medio y largo plazo estaba justificándose por vía metafórica.

3 Casetti contempla grandes constelaciones metafóricas que subtienden las metáforas forjadas sobre algunos medios. Sin duda en su clasificación caben tanto las metáforas «populares» o difundidas de una u otra manera por los mismos medios («espejo con memoria» o «pincel de la 
naturaleza» referidas a la fotografía, , «ábrica de sueños» o «lengua escrita de la acción» referidas al cine, «ventana abierta al mundo» o «caja tonta» referidas a la televisión, por ejemplo) , como las metáforas especializadas o «científicas», como las bien conocidas entre los investigadores de comunicación de masas de la «aguja hipodérmica», de la «bala», de la «espiral de silencio», del «flujo planificado», etc.

4 En el Aleph, bola mágica, torbellino de imágenes simultáneas en un mismo punto «sin superposición ni transparencia», el narrador Borges veía «todo el inconcebible universo»: mares, llanuras, ciudades, montañas, albas, ocasos, tierras incógnitas, pero también barrios, estancias, recuerdos, objetos personales, aromas e incluso secretos, sospechas o misterios por fin desvelados (Borges 1986:199). El panóptico de Bentham era el proyecto arquitectónico de una cárcel modelo. Al sustituir la oscuridad y el hacinamiento por la holgura de espacios y la visibilidad de los recintos de reclusión, la vigilancia del preso era más fácil, sobre todo porque éste interiorizaba la condición de vigilado y la necesidad de la conducta apropiada. Es decir, el preso era consciente de que podía estar siendo vigilado en cualquier momento, aunque no pudiera constatar esa vigilancia en ningún momento. Bentham sugirió que esta reforma panóptica de prisiones pudiera adaptarse a otros usos, como la escuela, la fábrica y el hospital (Bentham, 1979). Michel Foucault ha hecho una impresionante descripción del panóptico de Bentham (Foucault, 1996, 199-230). Allí afirma: «Nuestra sociedad no es la del espectáculo, sino la de la vigilancia [...] No estamos ni sobre las gradas ni sobre la escena, sino en la máquina panóptica, dominados por sus efectos de poder que prolongamos nosotros mismos, ya que somos uno de sus engranajes» (220). Sobre la herencia del panoptismo en el ensayismo apocalíptico reciente, cfr. Rodríguez Ferrándiz, 2001.

5 Quizá la evolución más notable de las metáforas asociadas a las nuevas tecnologías, en su todavía corta historia, es la que ha llevado desde la órbita del almacén, del depósito, del archivo (sólido digamos, localizado), a la órbita de la conectividad, del acceso, del alcance (gaseosa o, si queremos, etérea, deslocalizada). En este sentido José Luis Brea ha contrapuesto recientemente, utilizando la propia terminología informática, una cultura-ROM a una cultura-RAM. Mientras la primera garantiza la conservación de los patrimonios y los saberes, ya bajo la forma de documento- si ha adquirido forma textual- ya de monumento -si espacial, es decir, es una memoria de consignación, un depósito donde se almacena y que permite recuperar, la segunda en cambio es una memoria de procesamiento, dinámica, una arquitectura relacional que interconecta, vincula y distribuye el conocimiento, una constelación de saberes que también es fábrica y producción nueva de los mismos. La exigencia del usuario de tecnologías telemáticas ya no es tanto la capacidad de almacenamiento y archivo de su terminal, sino sus posibilidades de conectividad, pues el acceso a la red garantiza la disposición puntual de aquello que interesa en cada momento, y también de usabilidad, porque se trata de poder operar con eso a lo que se accede (y no sólo contemplarlo o consultarlo), y acaso devolverlo al tráfico de la red modificado, personalizado (Brea, 2007). Es decir, una cultura que sigue archivada, sí, pero no para poder olvidarnos de ella, sino sujeta a manipulación recreadora, a interminable masajeo (consultas, clasificaciones, recopilaciones, antologías, mixturas y alteraciones sin cuento), operaciones de apropiación que sin embargo no atesoran o exhiben como una propiedad exclusiva el resultado, sino que lo vierten inmediatamente en el mismo flujo de donde tomaron su material. 
6 Es paradigmático a este propósito el caso de Jean Baudrillard (1991). El autor francés, como es sabido, publicó en el diario Libération un artículo títulado «La Guerra del Golfo no tendrá lugar» en enero de 1991, poco antes de la fecha del ultimátum para la retirada de las tropas iraquíes de Kuwait. La Guerra comenzó, pero Baudrillard se empeñó en negar la evidencia de la guerra real amparándose en la fantasmagoría de videojuego que nos daban por imágenes de la guerra, como si de la guerra no hubiera más pruebas que esos documentos amañados e higienizados, en gran plano general del cielo cruzado por misiles: «¿Está teniendo lugar realmente la Guerra del Golfo?». Para cerrar la trilogía publicó, ya finalizada la guerra en marzo de 1991 y contra toda evidencia de su real acaecimiento y de sus funestas consecuencias, el texto «La Guerra del Golfo no ha tenido lugar», nombre que recibió el libro en que se recogían todos esos textos (París, Galilée 1991). En el primer texto decía Baudrillard: «La convicción más extendida es la de una correlación lógica entre lo virtual y lo actual, según la cual toda arma disponible no puede no ser utilizada un día, ni una concentración de armas semejantes no abocar al conflicto. Ahora bien, tal cosa responde a una lógica aristotélica que ya nada tiene que ver con la nuestra. Nuestro virtual supera definitivamente lo actual, y tendremos que contentarnos con esta virtualidad extrema que, a diferencia de lo que sucede con Aristóteles, disuade de pasar a la acción» (15). Y así los rehenes eran muertos «virtuales», que Sadam presentaba como huéspedes (de una hospitalidad también virtual), lo mismo que las amenazas de EE.UU. (como toda amenaza) eran ya de por sí una virtualidad. Así las cosas, y considerando además «nuestro temor obsesivo a todo lo real, a cualquier acontecimiento real, a cualquier violencia real, a cualquier goce demasiado real», era más que probable que la guerra no tuviera al fin lugar. La guerra sólo sucedería in vitro, en ese vidrio de lo virtual que es la televisión. Dice Baudrillard: «la guerra no queda al margen de esta virtualización que es como una operación quirúrgica» (17). En el segundo texto, ya con la Guerra del Golfo en plena escalada, la ausencia de imágenes y profusión de comentarios sugieren a Baudrillard una comparación con aquella marca -GARAPr que recordaba en su libro El sistema de los objetos: una marca que no correspondía a ningún objeto, y sobre la que todos especularon sobre qué podía ser. Tal la Guerra del Golfo: un despliegue publicitario y especulativo, virtual (19-21). En el tercer texto, ya concluida la guerra, Baudrillard la sostenía sin enmendarla: «Pero esto no es una guerra [...] 10.000 toneladas diarias de bombas no bastan para hacer que esto sea una guerra» (65). Para imágenes reales de la guerra, nada mejor que recurrir a las contundentes fotografías de Kenneth Jarecke, como la del soldado irakí carbonizado con el fusil en ristre y en fiera pose de combate.

7 Lev Manovich nos ha recordado recientemente que si bien Internet es una red globalmente homogénea, por la cual millones de personas muy distantes entre sí comparten los mismos instrumentos y protocolos, ello no quiere decir que sea percibida de la misma manera en todo el mundo. Y señala que mientras un artista occidental, por ejemplo, considera Internet una herramienta perfecta para eliminar las jerarquías y llegar a un público antes ajeno e inaccesible, un sujeto poscomunista, como él mismo, criado en la URSS de Brezhnev, tiende a ver la red como un piso comunitario de la era estalinista, donde no hay privacidad, todo el mundo espía a todo el mundo y siempre hay colas para acceder a las zonas comunes como el baño o la cocina. Es decir, una interactividad, si queremos «totalitaria», y no una interactividad invariablemente libertaria (Manovich, 2005, 14-15). 


\section{REFERENCIAS BIBLIOGRÁFICAS}

Abril, Gonzalo (2003). Presunciones II. Salamanca: Junta de Castilla y León.

(2003). Cortar y pegar: la fragmentación visual en los orígenes del texto informativo. Madrid: Cátedra.

Abruzzese, A. y G. Montagano (eds.) (1992). Caro Enzensberger. Milán: Lupetti.

Baudrillard, Jean (1991). La Guerra del Golfo no ha tenido lugar. Barcelona: Anagrama.

Bauman, Zygmunt (2000). Modernidad líquida. Buenos Aires: FCE.

Bentham, Jeremías (1979): El panóptico. Madrid: La Piqueta.

Bettetini, Gianfranco y otros (2001). I nuovi strumenti del comunicare. Milán: Bompiani.

Borges, Jorge Luis (1997). El Aleph. Madrid: Alianza [1949].

Brea, José Luis (2007). Cultura_RAM: mutaciones de la cultura en la era de su distribución electrónica. Barcelona: Gedisa.

Casetti, Francesco (1992). «Lettera a Enzensberger». En A. Abruzzese G.Montagano (editores). Caro Enzensberger. Milán, Lupetti, pp. 45-51.

De Bustos, Eduardo (2000). La metáfora. Ensayos transdisciplinares. Madrid: FCE.

Debray, Régis (1994). Vida y muerte de la imagen. Historia de la mirada en Occidente. Barcelona: Paidós [1992].

Deleuze, G. y F. Guattari (2000). Rizoma (Introducción). Valencia: Pre-Textos [1976].

Foucault, Michel (1996). Vigilar y castigar. Madrid: Siglo XXI [1975].

Giraldo Ramírez, María Elena (2004). «De la cultura de masas a la cultura mediática: un análisis de los media desde la comunicación», Anagramas Vol. 3, No 5, pp. 91-113.

Gombrich, Ernst H. (1979). Arte e ilusión: estudio sobre la psicología de la representación pictórica. Barcelona: Gustavo Gili.

Gubern, Román (1997). Del bisonte a la realidad virtual. Barcelona: Anagrama. (2000). El eros electrónico. Madrid: Taurus.

Indurkhya, Bipin (1992). Metaphor and Cognition: an Interactionist Approach. Dordrecht: Kluwer Academic Publishers.

Anagramas, Volumen 7 No. 13, pp. 165-180 • ISSN 1692-2522 • Junio/diciembre de 2008/232 p. Medellín, Colombia 
Lakoff, George, Mark Johnson (2007). No pienses en un elefante. Madrid. Editorial Complutense [2004]. Maldonado, Tomás (1994). Lo real y lo virtual. Barcelona: Gedisa [1992]. (1998). Crítica de la razón informática. Barcelona: Paidós.

Manovich, Lev (2005). El lenguaje de los nuevos medios de comunicación. Barcelona: Paidós [2001].

Mattelart, Armand (1994). La comunicación-mundo. Historia de las ideas y de las estrategias. Madrid: Fundesco.

(1995). La invención de la comunicación. Barcelona: Bosch.

(1998). La mundialización de la comunicación. Barcelona: Paidós.

Mattelart, Armand y Michèle (1987). Pensar sobre los medios. Madrid: Fundesco [1986].

Nunberg, Geoffrey (compilador) (1998). El futuro del libro. Barcelona: Paidós [1996].

Ong, Walter (1987). Oralidad y escritura. México: FCE [1982].

Ortega y Gasset, José (1991). La deshumanización del arte. Madrid: Alianza-Revista de Occidente [1925].

Rodríguez ferrándiz, Raúl (2001). Apocalypse Show. Intelectuales, televisión y fin de milenio. Madrid: Biblioteca Nueva.

_ (2002). «Virtualmente suyo», En: Telos 51, pp. 13-18.

Sartre, Jean-Paul (2000). Las palabras. Barcelona: Círculo de Lectores [1964].

Sodré, Muniz (1998). Reinventando la cultura: la comunicación y sus productos. Barcelona: Gedisa.

Tortosa, Virgilio (2008). Escrituras digitales. Tecnologías de la creación en la era virtual. Alicante: Publicaciones de la Universidad de Alicante.

Virilio, Paul (1997). El Cibermundo. La política de lo peor. Madrid: Cátedra.

Virilio, Paul (1999). La bomba informática. Madrid: Cátedra [1998].

Wolton, Dominique (1999). Sobre la comunicación: una reflexión sobre sus luces y sus sombras. Madrid: Acento. Gedisa. (2000). Internet, ¿Y después?: una teoría crítica de los nuevos medios de comunicación. Barcelona:

Yus Ramos, Francisco (2007). Virtualidades reales: nuevas formas de comunidad en la era de Internet. Alicante: Publicaciones de la Universidad de Alicante. 